Author

SF 429

AbL

Imprint

$18-47372-2 \quad \cos$ 




\section{YOUR AIREDALE By W.H.Linǵo \& J.Horace Lytle}

A reasonably complete treatise on the care, raising, training, and handling of the AIREDALE TERRIER from puppyhood to full growth. This is compiled from actual experiences as proven successful in the raising of the famous strain of Oorang Airedales at the Oorang Kennels of LaRue, Ohio.

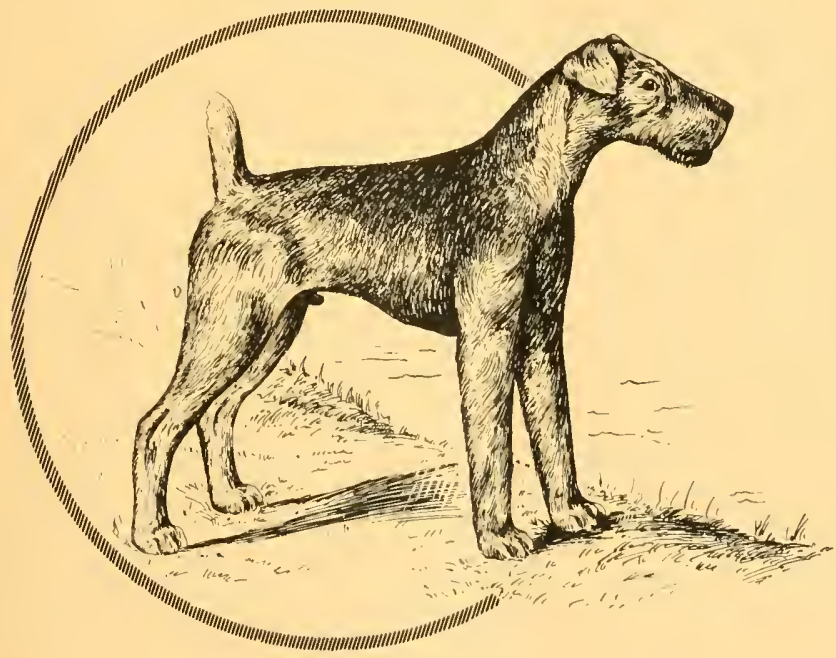

The Largest Breeders Airedale TerriersintheWorld
OORANG KENNELS
LARUE OHIO 


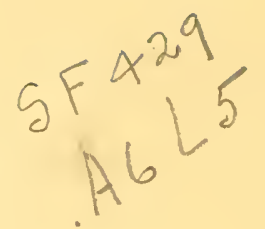

Copyright, 1917.

by

W. 11. LINGO

LaRue, Ohio

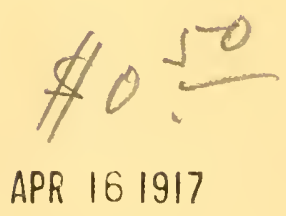

\section{PRIGE PER COPY, FIF'TY GENTS}

(C) $\mathrm{Cl} A 459433$

$2 n 01$. 


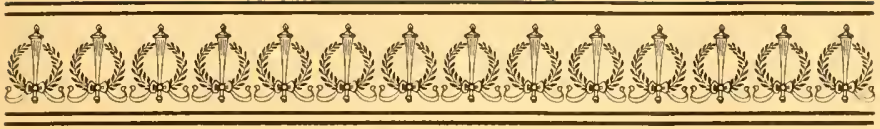

\section{GENERAL INFORMATION}

IL Oorang Airedale puppies are shipped crated in light but
secure pine boxes and with sufficient food to carry them
through to their destination. We Guarantee Safe Arrival at any point within the United States. This Guarantee means that should any accident occur in transit, we will promptly ship another pup to you. In such case we collect from the Express companybut you have no responsibility in the matter at all. You get another pup at once. We deliver all dogs at the express office here, and make live stock contract with the Agent, in your name, and secure the lowest possible rate.

When you receive your pup be sure to examine it carefully in the presence of the Express Man and call his attention to anything you find wrong with either the crate or the pup. Our pups are always shipped from LaRue in the very best of condition and will reach their destination in good shape when given proper care and attention by the Express company. Let us hear from you when the pup arrives.

When you take your pup home give it a good bath, using either Ivory or some good dog soap, lather freely and rub well into the skin. Then cleanse with clear water and give "rub-dry" with a rough towel; and make very sure that the pup is not exposed to the cold before being thoroughly dry.

Oorang pups are all hearty and strong; but they are farm raised and, therefore, are not guaranteed to be flea proof. So do not be alarmed if he scratches; treat any sore spots with vaseline. The lather of the soap will kill all parasites.

Oorang pups are thoroughly wormed when six weeks old; but should be given another treatment at about the age of three months. Any signs of constipation should be remedied by giving a tablespoonful of castor-oil. Oorang pups have been raised and kenneled out-doors, so do not be afraid to give plenty of exercise and fresh air. Correspond with us at any time for any special information that you require or desire.

When your pup arrives do not expect him to look like a matured Airedale. He will not. Airedales change more with maturity than almost any other breed. The pup's coat will be short; and his head will be broad and short. As he grows older, his coat will become longer and more wiry, and the tan coloring will begin to extend upward until finally the head, ears and legs become nearly all tan; and the shoulders and thighs will also become tan color up to the point of joining the body. As the pup's head becomes more proportioned with maturity his fore face will lengthen and straighten, and should also become whiskered by the time the pup is around eight months of age.

A trait largely peculiar to Aircdales, is the fact that puppies are often inclined to timidness, thay may be particularly shy even with 
their masters, and yet will outgrow this disposition after they become older. An Airedale may often retain this shyness or apparent timidness, until after he is past his first year of age, which, we must confess, is a unique trait in a dog of such inherent gameness-though we must remind you right here that an Airedale will very seldom ever give you trouble from starting a quarrel. Yet in the ease of an Airedale, even the most timid of pups develop with maturity into the very best and bravest of game killers, exhibiting quite a reversal of form, an early indieation of shyness during puppyhood. Do not be discouraged if your pup is even hard to train to eome when you eall him, although timidness to such an extreme as this is unusual. However, should your pup be as shy as this, we might suggest that you try ehaining him up for several days in a location where there may be persons passing eontinually, partieularly strangers, and where there may even be a certain amount of noise and confusion. Even though this process may aecentuate his shyness for a day or so, he will soon become more and more aecustomed to the things that he sees and hears around him, and will gradually develop a more sturdy disposition.

Patiently and carefully work towards helping your puppy develop confidenee in himself and in his surroundings. Should he become frightened, do not abuse him, but patiently encourage him and show him that his fears are unfounded and unnecessary. It will be bad for your pup if you confine him too much; likewise it will be equally bad if you allow him too much liberty, as the latter may encourage him in the habit of becoming a tramp.

\section{FEEDING}

One thing to whieh you should give special attention is the feeding of your puppy; and we have found that, where there are but one or two puppies to a household, the best food for them is the scraps from the table, with a few exeeptions. Do not feed your pup ehicken bones, as these are so small, brittle and treacherous for a young dog to handle, that they are very likely to pieree the walls of the intestines. Also do not feed a young pup potatoes, as potatoes are a food not easily digested by a dog's stomach. However, all other forms of vegetables, soups, gravies, etc., are good for your puppy. Oatmeal is good. The Soy bean is good. Mush is good for him. An especially good puppy food is to make a mush with a meat soup flavor. It is well to give the pup butter milk and sour milk from time to time, as these will help to keep down the worms. Of course, we want all of our patrons to feel free to call upon us at any time for any special information that they may feel necessary in order to help them raise their pups into that splendid mature specimen that is our hope and theirs for him to beeome.

When you feed your pup soups, gravies, mush or broth from boiled meat and mutton, be sure to let it cool before giving it to the pup. Never give a pup too muel milk to drink. To the novice this may sound like strange adviee-but most puppies are fed entirely too much milk, so be very eareful to feed your pup only a reasonably limited amount. Pasteurized camned milk is a very good foor for rogs, particularly if somewhat thinned with about a third part of 
lukewarm water. Always bear in mind that one of the worst things you can do is to give the puppy too much to eat. This is a common fault with owners of only one or two pups. Of course, you must always feed a sufficient amount-but it is better to always have your pup willing and even anxious to eat more than you give him. If he ever leaves uneaten food in the pan, the chances are you have fed him entirely too much - a dangerous thing to do.

A puppy from two to four months of age had better be fed about five times a day-but not too much at any one time-instead of overloading him in a fewer number of meals. This plan gives him a longer time to develop smaller quantities of food as they are given. Between the age of four to seven months, it may be well to feed four times a day; and from seven months to maturity feed three times a day. Be sure and feed at regular hours-and do not give the pup any food between his meals. Some persons feed a fully mature dog twice a day, morning and evening; but a great many authorities feel that a full grown dog, particularly if he has much freedom, and is thus able to forage for himself to some extent, needs but one regular meal a day, preferably in the evening.

\section{EXERCISE}

While a grown dog may not get enough exercise for his own good if he is permitted to lie around the house, never worry about whether your puppy is getting all that he needs in this respect. A puppy by nature is playful-and is continually at play of one sort or another. This play is exercise-good hard exercise-and all that he needs. Don't get the mistaken idea that you should give a growing pup long; hard or fast runs, or even such strenuous tramps following you on a long walk that he becomes exhausted. Never force a pup to unnecessary, unusual or violent exercises before his eating time; and allow him the full freedom of his natural desire to indulge in, at least, a short rest after feeding. In short, you have little reason to worry about your pup on the score of exercise, provided he is not penned up in some such enclosure that does not even permit of his having a chance to play.

\section{YOUR DOG AND POULTRY}

Some dogs naturally love to chase or kill chickens or other poultry; while to others this desire does not seem to come naturally. The writer has known dogs that would kill every duck on sight and glory in doing so, despite continued punishment-and yet many of these same dogs would never think of bothering a chicken. These tendencies of mature dogs are often largely due to early training, or lack of training, and the thing to do is to begin while your puppy is young and not permit him at any time to indulge himself in the chasing of chickens or other poultry. The great troub!e in many cases is that an owner will permit a pup to chase chickens once or twice just for the fun of it, while the pup is still very young, and they expect later to break the dog of the habit. This is a very bad plan-and the thing to do is to start right in from the beginning and never encourage-but always discourage-any evidenced tendency 
on the part of your pup to chase poultry. If you once let a dog get the poultry killing habit, you will have some problem on your hands; but it will not be a very serious muter if you start right in at the very beginning to prevent the log from such a habit. If the tendency starts to get the better of you and if a few severe whippings does not tend to correct the evil, we might mention the following plans which are recommended by some dog authorities. If the dog has killed a chicken, take this chicken that he has killed and fasten it securely to the dog's collar and leave it there for a number of days. While this treatment is going on, see that the dog is often in the midst of live poultry, and authorities claim that in most eases this may bring about, at least, a temporary cure. In other words, the dog gets his fill of chickens after he has been lugging around a nine or ten pound, clead rooster, suspended from his neck for a couple of weeks. But, it is our opinion, that the best way to cure an Airedale from killing poultry, is to begin right with your puppy when he is very young and don't let him make the mistake in the beginning of even getting started with the gratification of any natural tendency in this direction.

It is not often likely that a grown Airedale will take kindly to a strange cat, as the Airedale is a terrier and cats are almost universally one of the terriers' enemies. However, if you have a cat in your familty and bring up your pup with that cat, your Airedale will not only never molest the cat himself, but he will, at all times, protect it from intruding dogs. Yet, you may not be surprised if youl own Airedale is, himself, an enemy to strange and stray cats.

\section{WHERE YOUR PUP SLEEPS}

Your pup should have a clean, warm, dry and sanitary place to sleep. If he sleeps on sawdust or straw, be sure that this is changed and kept fresh for him at least once every week. An improvised kennel can be marle from a barrel and will be found to be one of the best sleeping quarters that a pup could have. A barrel retains the heat from the dog's body in good measure, and it is almost impossible for drafts to penetrate. It is a very simple matter to so secure the barrel that it will not roll when turned over on its side, which is its proper position for a kennel-and, of course, with but one end knocked out. It would be well to use a little powdered sulphur in the barrel before bedding it down with fresh straw or sawdust. When the weather is cold, hang some sort of a heavy curtain over the opening of the barrel to keep out the wind, but, so that the pup may pass in and out, do not tack the flap of the curtain at the bottom.

\section{THE EARS}

It is important that you should give special attention to your pup's ears, particularly while he is very young and during the period while his ears are developing. As your pup grows and his skull gets larger, the set of the ears begins to develop more certainly, and at around four months old you may expect to see them begin to push forward into correct position. At about this age of the pup, do not be surprised or discouraged if one ear takes its proper position 
before the other one, while the other ear still droops. Very soon you will find that the museles of the drooping ear will also develop enough to hold it up and forward too, and then the pup will carry both ears well up and in place. It may sometimes-but not very of ten-be advisable to assist the pup with the drooping ear by using a little surgical plaster to assist the weak muscle. But never try to urge the ear forward while you have this plaster on. Keep up these plaster strips for a week or so and then see if the muscle is not strengthened enough to hold the ear in place without further help. It is not often that it will require more than a week or so to accomplish this result--and, in fact, it is not often that the plaster itself, needs to be used at all. However, the point that we want to make clear is that the ears and their growth during puppyhood should be watched carefully and given attention, if necessary.

\section{YOUR FRIEND}

You will never have a better friend than your Airedale, and the time to start to develop this fricndship is when your puppy is young. Play with him whenever you have an opportunity, whether it be indoors or out. Take him walking with you when you can conveniently do so. You will find that this will not only bind you and the dog into a close comradeship, but you will also find that being in company with you will tend to develop the different traits that the dog may have, and he will become more valuable to you in many ways from learning to know what you want and what you expect of him. An Airedale is naturally such an intelligent dog that no one ought ever to even think of confining him to solitary kennel existence. An Airedale is an appreciative animal and will show you this in many ways - and one of the things that he appreciates most of all is friendship; particularly if the friendship be that of his master.

\section{IS HE HOUSE BROKEN?}

Of course, when your Oorang puppy comes to you he will not be house broken, as Oorang Airedales are all farm raised in the open. It is not a difficult matter, however, for an Airedale to soon become house broken. One good way to accomplish the desired result is by first training your pup to a collar and lead (and this is something that you ought to do anyhow.) When he is about three months old, you can fit a collar on him, but always be sure with the puppy that you watch the collar every two or three days to see that it has not become too tight. One of the most serious things you could do would be to put a collar on a puppy and then forget to watch it for a certain time-for puppies will grow rapidly and serious damage may easily result when his neck gets too large for the collar. The best collar for an Airedale is usually a round (or rolled one.) A flat collar interferes with the proper development of the coat on his neck. After getting the proper collar, also secure a light lead, preferably of aluminum, and gradually accustom the puppy to collar and lead. One or two lessons ought to be sufficient for this purpose. If a pup is a bit timid or shy, do not lose your temper, but be patient with him and even pet him. 
Now then, when you have your puppy ateustomed to the leat, that will offer one of the best means of training him to become house broken. Ifeep him on the loat when he is in the house, and when you leave him in the house, tie him, if possible, and this keeping of the puppy under restraint while he is in the house will tend to make him associate with coming indoors a realization of the fact that the house is not supposed to be a puppy's play-ground and pillows and rugs were not made merely for puppies to play with and pull apart. However, you will of course realize that the puppy should be taken out of doors frequently, and each time release him from the lead, so that you will fix in his mind the idea that indoors means restraint, while in like manner he associates the outdoors with entire freedom. By careful treatment, and intelligent treatment, it will be surprising to you how quickly your puppy will come to form neat and elean habits in a way that will surprise you.

\section{THE PUP'S EDUCATION}

The first thing you want your pup to do is to mind you; and the way to educate an Airedale to the habit of obedience is by kindness, supplemented by holding out to him the hope of reward. By this method, supplemented by an Airedale's natural intelligence, your log will develop along most any lines you desire him to do. Naturally your dog must have confidence in you-but before he will have this confidenee, remember that you must merit it. In other words, you must earn his confidenee, as the result of the way you treat him and continue to treat him.

A little careful, judicious and continuous care on your part-and you will not have a great deal of difficulty in teaching your dog to "lie down" at your command. One thing you must always remember in training your pup, is the fact that you must make an effort to SHOW HIM what is wanted. When you are teaching him to "lie down" at command, a good way to do is to gently, yet firmly push down on his back until he does lie down and understands what you mean by the command. Then, if necessary, carefully hold him in that position a short while; after which release the hold and give him the command to "get up." He will soon learn to obey you and understand the commands, and you should keep encouraging him by patting him when he is obedient and also regarding said obedience with some little delicacy that he likes to eat. Do not give him too many lessons at one time, as the best results are to be secured from oft-repeated lessons in which you are trying to train him to do. It is bad to keep up the training at one time so long that you tire the pup or cause him to become decidedly discontented. 'Training a alog is always a valuable lesson for any man-qualify in having patience. It will be good for you to work with your dog if you develop patience and control by so doing. It is not an easy thing to train a dog, or any other animal in fact-and in some eases it often seems to be a discouragingly thankless task. But a little kindness and perseverance will enable you to work wonders with an Airedale. There are many things that you will want to teach your dog, such as to walk up close at your heels when you desire-or to "heel" as it is generally called. 'This command will be taught by 
using the same nuthods of suggestion as in the case of teaching the dog to lic "lown. Then when you say "on, boy," teach him to associate this command with entire freedom to run, hunt, or whatever it is the intention that he shall do. Before he gets entirely accustomed to this command, and even after the preliminary training, a good plan is to wave your arm forward in the direction in which you wish him to go, simultaneously with giving him the command "on, boy."

It is a nice and valuable thing to have your dog mind you at all times and under any conditions, whether it be in the country, or in the crowded city streets. But, particularly in the latter case it is almost essential that your dog shall mind you immediately and absolutely, as an assistance in preserving his life when he is crossing a crowded street with you in the midst of motor cars, street cars and other vehicles. The command of "heel" is a particularly valuable, even necessary one for a dog that is to be much in the city.

Your dog need not be much over three months old before you begin to school him along various lines, always remembering patience, and being careful never to give him too much at once. The Airedale is too intelligent and also too sensitive to lend himself well to training by any methods that may have proven successful in the case of other breeds. Force will never accomplish your desired end with an Airedale. But no dog, or any breed, trained by force will ever be fully the equal of another dog of equal intelligence, no matter what the breed, if the latter dog be properly and thoroughly trained by methods that have had kindness as a basis. Do not misunderstand us-punishment may have, and often is, necessary. But it is just as necessary that punishment be administered only in the proper manner and always tempered by cool judgment. Too much punishment under any circumstances, is bad-therefore if you must punish, and when you must punish, do it well. Use a strap or a whip to administer your punishment-never grab a club or anything that might injure your dog or beat too severe and brutal. Do not call your dog to you when you are going to punish him-go to him. You encourage disobedience in him if you call him to you when you are going to punish him.

Naturally you will want your dog to come to you promptly when you call him. It is a fine thing to have a dog that, will come on the run when you call him. A good way to train him to do this will be to always call him with the same call or by the same whistle that you use when you are going to feed him. This will cause him to get into the habit of coming to you on the jump when you call. It is not within the scope of this book to go into details covering the many possible things that our customers may wish to train their pups to do; but it is our intention to merely point the way and give you the basic idea of proper training-and then, along the same general lines as we have indicated for the few things we have covered, you can train your Airedale to do practically anything that you want him to do.

\section{HUNTING}

Many of our customers may want to train their dogs for hunting purposes, and an Airedale lends limself remarkably well to training 
as a hunter. An Airedale is unquestionably the best water dog as has ever been discovered. They may often be trained to point birds like a pointer or setter; they make splendid dogs to trail game like a hound, whether they be foxes, rabbits or even big game in the daytime, or coons and possums at night; they are unequalled as retrievers for ducks, where their abilities in the forest will outshine the work of any other breed of dogs. When your pup is young, you want to avoid allowing him any chance to become gun shy, as you will appreciate without much discussion on our part, that the time to prevent any bad traits is in the beginning before they get started. Your Airedale will never become gun shy if you proceed in the proper manner to accustom him to the sound of a gun. Don't take a naturally timid puppy for the first time to a trap exhibition and frighten him to death with a steady cannonade of shot gun fire, and do not even go so far as to begin shooting off a gun around his kennel at home, for then his sole attention will be attracted by the shooting and this may frighten him from the fact that he has nothing else to think about. To accustom a young dog to fire arms, the thing to do is to know that his interest is abosrbed in some objeet of the sport, so that the discharge of the gun is merely incidental and he hardly notices it. Iet your pup be interested in chasing a bird or in trailing a rabbit, and incidentally shoot off a gun, his mind is thus occupied-and there isn't one chance in a great many that he will even notice the gun; and he will soon become unconsciously entirely accustomed to fire arms. Of course, discharge the gun with moderation in the beginning, and do not start a camnonade over your dog even when he is interested in some game. The best plan is only to shoot once or twice on each individual occasion for a whileuntil finally success will reward your pains and you will find that no amount of shooting will bother your dog, if you have observed our instructions carefully.

\section{TRAINING TO RETRIEVE}

While, as we have explained, an Airedale is valuable in multitudinous ways - still there is nothing that he takes to more naturally than retrieving. He is a born retriever. And you should not have any great difficulty towards training him to perfection along this line. Many authorities claim that the best thing for lessons in retrieving is a roll of cloth, bound with string, and wrapped to a size not much larger than a quail. A ball is apt to be either too hard or too soft, but a roll of cloth of cloth just answers the purpose. Do not be too playful in teaching your dog to retrieve, or he will not take it seriously enough himself, and wi!l only obey your commands until he is tired of the sport. It goes without saying that to be a valuable retriever your dog must always take the thing seriously and be unconditionally obedient when you tell him to "feteh," or whatever command you hit upon as being the one you will use when you want him to bring something to you.

We do not recommend drilling your pup for more than fifteen minutes to a half hour each day in the beginning, and it would be just as well to have him on the lead when you are giving him his initial lessons. You should stand facing the same way that the dog happens to be looking, and, try to interest him in the roll of cloth in 
your hand, toss it from you a short distance and see if he has an inclination to go get it. If so, and many pups will-the lesson is much simplified. Let him lead you to the roll of cloth, or other object used, and in many eases he will pick it up and give it to you. If he does not do this naturally, try to encourage him to do so. If he wants to romp and play with it, be just a bit firm with him and urge him to deliver it to you. Then toss it away again and repeat the performance until you get him to be willing to deliver the object to you voluntarily. Always reward him well when he performs well, encourage him, pat him and speak to him.

If he does not naturally pick up the object and either wants to romp with it or give it immediately to you, the lesson is not so simple for you and training him will require careful patience on your part. The thing to do in this case is to gently but firmly force open his mouth with one hand and insert the object with the other hand, and then gently but firmly hold his mouth closed on the object for a brief period. Then, release your hold on his mouth, order him to give the object to you-and praise him voluminously when he does so. Patience, eare, judgment and repeated practices will finally bring you just reward in even the most extreme cases-but, we repeat, an Airedale is a born retriever.

\section{HUNTING AND KILLING}

The sturdiness of an Airedale, his gameness, dexterity and activity, his heavy coat, and his long, powerful jaw makes the Airedale a deadly fighter-and a killer of his game. Many dogs are reasonably good fighters-but an Airedale fights to kill; and he either does kill or is himself killed in the attempt. Few dogs can punish like an Airerlale-and but few will dispatch their game so promptly. An Airedale will kill, single handed, game that often requires, in the case of other breeds, at least two dogs working together. We refer particularly to such hard fighting game as the coon, badger, or wild cat. There are mighty few Airedales that are not able alone to dispatch such game even more quickly and decidedly as is usually the case of two dogs working together. And yet, on the other hand, even in the ease of larger game, where the Airedale himself is not the match for his prey, as in the case of a bear for example, his cleverness, rapidity of action and dexterity is such that an encounter seldom results fatally for him, as he keeps out of harm's way in a manner that mighty few other dogs are able to do.

Starting with your puppy to train him to become a killer of game, nothing is better than a rat for him to work on. When your pup is from four to six months old, confine him in a compartment with a rat-and have no fear that he will be able to take care of himself. The youngster will soon become quick in his work of killing; and as he increases his dexterity, and as he becomes more matured, you may gradually increase the number of rats that you give him at one time, until, when he becomes a full grown dog he will be able to take care of himself and simply murder any quantity of rats that you could box him up with. If you want him to become a killer, and have no scruples about doing so, you might allow him to chase stray 
cats. But do not expeet an Airedale of less than a year old to do much heavy fighting unaided. After an Airedale is from a year to eighteen months old, he is more than a mateh for most anythingand will willingly and eagerly tackle anything that there is to be tackled. But, as we have before stated, quite the reverse is true until an Airedale reaches maturity. If you ean hunt your pup on coons with an experienced hunting dog, provided you do not start him on such hunts when he is too young and not strong enough to stand it, you will find that this actual experience will be a good way to break him in. But do not turn a pup Airedale loose on a full grown one. Better let the other dog kill the coon, or almost do so, before you let the pup jump in and take a hold of him. But be sure that you do let the pup jump in and get his full taste of blood at the proper time, and when there is no chance of his experiencing a good licking while he is still nothing but a youngster.

An Airedale is today the most popular dog for the hunting of big game; and an Airedale that has been hunted on any sort of game will take naturally to hunting larger game when the opportunity is given him. If you are not, yourself, in a big game country, it is often possible to find some reliable hunter who will take your dog and train and work him on big game for you at very reasonable expense. But a word of caution must be injected here-for the height of folly would be to send your dog away to someone whom you are not previously positively sure of. We, at LaRue, are usually in touch with a few persons around the country who are reliable big game hunters and to whom it would be perfectly safe for you to entrust your log for training. W' $\mathrm{e}$ will always be glad to advise with our customers on this point, as on all others, if they will communicate with us.

\section{WORK ON THE FARM}

Not all persons have equal ability to train a dog to do what they want him to do; but the ability to handle and develop a $\log$ may be learned by careful attention and study of this interesting art-for it is an art. Dogs on farms may be valuable in many cases, most of which comes natural to an Airedale, but this article will deal with training your dog to become a good shepherd or cattle dog, as aptitude for this work is something that must be developed. Although many farms have dogs of Collie blood, nevertheless a really well trained and valuable cattle or sheep dog is somewhat more of a rarity than ought to be the ease. There are several breeds of dogs that can successfully be rleveloped into working stock on a farm, and one breed that lends itself well to this sort of training is the Airedale.

To train your dog to successfully work sheep or cattle on a farm, the best time to start the lessons is while the dog is still a puppy. Older logs are often developed for the work-but their training is never quite so easy as when you start his work on this line while he is still a puppy and susceptible to a proper direction of his habits. We have already spoken earlier in this book of the elementary lessons of obedience, and of course, these should be thoroughly 
mastered before proceeding to the higher stages of development and training for a different purpose.

When your pup is about ten months old, and has gotten so that he will obey you in all elementary commands, take him with you every day when you go out with the stock, and familiarize him gradually with the work about the different animals, both out on the farm, in the barns, etc. Of course, exercise great care your pup does not develop a tendency to nervously run and jump about, or after any of the animals that it is your intention he should develop himself in learning to take care of. Allow us to say at this point, however, that before you can expect a dog to successfully drive cattle, those same cattle must first be accustomed to being driven by men-for if this is not the case, it is hopeless to expect a dog to accomplish what a man has not first been able to accomplish. A dog can only be taught to do something that he has first seen you do. Therefore any stock must first be handled by you, before the dog can ever learn to do so. Thus it will be seen that a proper discipline of your stock is equally important with the training of the dog.

When you first take the dog out with you, the best plan is to keep him right with you, and do all of the driving yourself, curbing in the early stages any tendency he may have to assist you-in other words, his learning must come from seeing what you do and following your example. Thus he will gradually learn from you what you doand the day will come when he can and will, do these same things successfully himself. Let us at this point again inject a word as to the need of patience on your part, for you must remember that the training will only be gradually accomplished, and you must not expect any dog to become a first-class stock driver in a day, or a week, or even a month. It takes time-and for you to be successful in properly developing your dog, you must always remember that it takes time. It is the writer's belief that you may develop your own expressions that you will use when you want him to go on, or come to you, or stop or be careful, etc., etc. It will also be possible for you to teach your dog the names of the various kinds of stock that he is to handle, so that he will know what you are referring to when you say "cows, sheep, etc." When he first begins to show proficience, should he ever bring you the wrong animals, go back with him to take them where he found them; and then get the right ones. But patience again-be careful that you do not discourage the dog by even a suggestion of harsh treatment when he has made an honest mistake - for you are very apt to spoil him right here if you do not remember this word of caution.

Of course, from the beginning you will guard against any tendency of the dog to injure stock from over enthusiasm in snapping at their heels, from allowing him to drive them too rapidly, etc. A good dog is always an ideal companion-but too much praise cannot be given for the value of a well trained dog on a farm. He will accomplish more with stock than three men could do. In the older countries of Europe a sheep and cattle dog is really taken very serjously, and in those countries he has been developed to real value. There is too prevalent a tendency in America not to take the stock dog sufficiently seriously. We urge you not to make this mistake- 
if you would expect to have a truly valuable worker, as it is possible for you to have if you go about training him at a task worth whileas they have found it to be worth while in England, Scotland, France and other countries of the whole world. We hope to see the time when there will be held in this country Trials for sheep and eattle dogs, as they are held in the old countries today, and as we in America hold trials for our bird dogs and hounds. There is no reason in the world why this splendid idea should not be encouraged, developed and materialized into an actuality. Although attempts toward this have not thus far been very encouraging in America, the time should come, and we hope soon will, when Trials for sheep and cattle dogs will be as possible as Trials are today for bird dogs and hounds. Cups and prizes should be offered for annual competition-and if properly worked out, the keenest possible interest should be taken in competition in these sheep and cattle dog Trials, not only among the contenders, but among large crowds of eager, interested spectators as well-as is the ease in England and some other countries. The work of the well trained sheep or cattle dog is just as valuable and just as interesting (or even more so), as the work of the bird dog or the hound.

\section{SHOWING YOUR AIREDALE}

When your pup becomes about six or seven months old, you may find that he is developing into such an apparently perfect specimen that you may decide to take him in hand and prepare him for the Show ring. The object of the following paragraphs is to assist owners of our Oorang Airedales to learn the fundamentals of properly training and showing a $\operatorname{dog}$ in orler to increase the chances of being successful.

If you have not groomed your dog well and regularly, his coat is apt to be in a rough condition, and all this outer coat should be taken off, down to the imner coat, before your chances of winning will be great if you are to show your dog. The thing to do is to pull out the outer coat by using the fingers and thumb, and then when the outer coat grows out again, it will be an entire new coat of an even length and age. You will not hurt the dog at all by pulling out his outer coat as we have suggested, as it will be done very easily. It will require two months or longer to grow a perfect new coat; although a soft coated dog may do so in only a few weeks time from the fact that a soft coat grows much more rapidly than a hard and wiry one.

Every day the dog should be well groomed or combed, with a fine steel comb, so as to take away all the soft hair. After which combing he should be well brushed with a good hard brush, finishing the grooming by a good rub-down with hound gloves for at least five minutes. The dog's coat will then lie close and dense, and will have a sort of polish to it. If you keep up this operation with regularity, be sure that the old coat is picked out thoroughly, you will find that a dog with a good naturally wiry coat can be kept in perfect Show ring condition all during the year. On the other hand, a dog that does not possess a naturally good coat should be stripped again a few weeks later, for the coat will soon grow too long and shaggy. Of course, if your dog does not have a good coat naturally, it is a 
hard matter to give him a really good one artificially; but much may be aceomplished along this line from following our suggestions regarding careful plucking and regular, systematic and conseientious continued grooming, combing and brushing.

At least a month before the show, you should make absolutely sure that the dog shows no suspicions of worms, and if he does, a good worm medicine should be used at once. We merely repeat at this point that we should be glad to have our customers keep in close touch with us at any time for advice; and we refer you to the advertisements in the back of this booklet. An overuse of drugs or medicines is bad for dogs, just as is the case with humans, and we do not believe in stuffing a dog full of all sorts of medicines or drugs while attempting to put him in Show condition. The proper diet, enough exercise, and strict cleanliness-these form the key-note for the greatest success. However, a teaspoonful of milk of sulphur in the food about once a week may be recommended as good to keep the blood in shape, free from skin disease, etc.

When training your dog for the show ring, give him a daily walk of an hour or so on a long lead (in addition to the exercise he gets in the ordinary course of events), and take him for this walk over a hard surface, if possible, for this will tend to help keep his feet and nails in shape. Furthermore, since in the show ring he will have to be surrounded by other dogs, persons, etc., it will be just as well when taking him for his walks to go in amongst traffic, other dogs and people-thus accustoming him to such surroundings. If your dog does not take kindly to the lead at first, patiently and carefully keep at it until he does become entirely accustomed to it and satisfied with it - for this is absolutely essential if a dog is to be successfully shown. We might say here that even some of the best dogs are naturally not good showers, which is a fact to be regretted; and a puppy must be trained and broken to Showing; if you would have him put himself off to the best advantage, just as he must be trained for anything else, whether it would be hunting, driving stock or what not.

With reasonable frequency, while you are training a $\operatorname{dog}$ for the Show ring, aceustom him to circling about you on the lead, and endeavor to have him keep his head up, tail erect, and show lots of life and fire and sparkle. A good way to get him to do this is to always have a few pieces of something that he likes very much to eat in your pocket, and give him these bits from time to time as a reward when he carries himself proudly and in a becoming way such as you desire. He will soon learn to associate these rewards with standing spiritedly at attention, and it will not be a hard matter to get him to show lots of spark and ginger whenever you put the lead on him and begin eircling about a small space with him. This is one of the best things to remember when training your dog for the Show-for that is exactly what he must do and how he must act when he must arise to the supreme effort hefore the Judge in the ring. Often and again the dog that shows the best will take the blue ribbon away from a competitor who may be even a little better in points-but who does not conduct himself to the best advantage when before the Judge. 
If it should be during the summer months that you are conditioning your dog for the Show ring, never exercise him mueh during the middle of the day; but select either the eool of the morning or evening. The dog should be fed all foods that will make for good substantial muscle-and not just fat. Be careful not to overfeed him but make the feeding light about three times daily, and regularlyand after exercise. Quite a good cliet would be, say, a dry dog biscuit for breakfast; a small amount of absolutely fresh, hashed raw meat, lean, at noon; and at night dog biscuits or bread mixed with vegetables and softened or slightly soaked with a gravy or broth.

Let us eaution the novice never to show a dog unless he has first been put in the pink of condition, and well sehooled in how to Show, for otherwise the dog may be defeated by a less valuable dog and you beeome discouraged at the outset. Such a discouragement might even cause you to foolishly part with your dog for an insignifieant sum to some observer who made note of his really valuable natural eharaeteristics and who knows that the proper sort of conditions would eause your dog to win. A Judge, you know, must judge the dogs on their appearanee and performance before him in the ring-without any consideration based on past performance or other qualifieations foreign to the one particularly showed at the time.

A Judge may often (and we reeommend it), show special consideration for the irovice and give him every opportunity to show his dog to advantage; however, if you are a novice, and have a really good dog, it will very likely pay you to arrange with a professional handler to show him in the ring, at least until both you and the dog become thoroughly accustomed to the Show ring and feel that you are able to legitimately wield all that is coming to you without the assistance of the professional handler. Watch all of the best handlers as they are performing in the ring and you should soon eome naturally and almost subeonsciously into the knack of it. A really competent Judge is more than likely to be an entirely fair one, so we would not advise you to amnoy him by continually tagging along after him as he examines the other dogs, and attempting to have him give special notice to your dog by having him continually under the Judge's nose.

If you start for the show in another town and must use a railroad, we recommend that it is the best not to feed the log before you start on the journey (of course, provided it is a short one); and we would also advise that after returning home from the show, it is a good idea to give the dog a dose of Epsom salts, as this will be very beneficial after his inactivity from lying around at the show for several days.

It should go almost with saying that, before entering your dog in any show, you should register him with whatever Kennel Club is responsible for the Show. The eharge for this is only $\$ 1.00$ and it will be valuable to you in many ways to have the dog registered. The addresses of the Kennel Cinbs that you are most likely to wish to register with, are the following: 


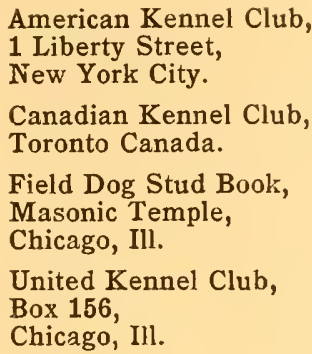

If any of our customers should desire more specific information on the subject of showing, and conditioning and handling for and at the shows, we should be glad, as in all cases, to have them correspond direct with us here at LaRue, and it shall be our pleasure to give any suggestions we can.

\section{BREEDING YOUR FEMALE}

Many breeders feel that they must breed their bitches to some famous bench show Champion. Yet breeding, to be rightly done, should be with a view to securing a combination of the strongest points of the two specimens mated. Even a Champion may be weaker in some points than a second rater. Now then, if your bitch happens to be also weak in the very same points as the Champion, IVHY MATE THESE TWO? Better mate her with the second rater who is stronger than the Champion in those same points where the bitch is also weak. This is one of the secrets of good breeding. If you mate two dogs having the selfsame faults, the result is only too likely to be that these faults will show up intensified in the offspring. The best breeders will always select a dog strong iu those points wherein the bitch may be weak. If his bitch has a rather short head, then he selects a very long headed dog for her. If the bitch has big, light eyes, she ought to be mated with a dog having especially small, dark eyes. If she has a light colored, soft coat, mate her with a dog having a good, wiry coat. If she is small of bone, mate her with a dog having plenty of it-a big strong boned specimen.

The general character of the dog's family should also be considered. What tendencies have his or her ancesters had to a marked degree? In other words, BREED TO CORRECT FAULTS. Not to accentuate them. Also, of course, in addition to trying to breed against the faults of either $\operatorname{dog}$-breed to retain their gond points. The one is as important as the other. In this connection allow us to say that we invite all those who purchase females from us to send them to us for stud service, and we allow stud service at one-half $(1 / 2)$ price to all bitches bought of us. What we feel is a good reason for your taking advantage of this offer is the fact that of course we know the blood lines and ancestry of both the bitch and our stud dogs-hence can mate the bitch with this intimate knowledge at hand, and along lines most likely to produce the best possible type 
of the Oorang strain. We are interested in developing Oorang Airedales to a point of the highest possible perfection-and this applies to all of the strain; it means that we are as interested that YOU should breed perfect specimens of Oorangs, as that we should ourselves here at LaRue. We are not only interested in your dogbut in the pups of your dog as well. Thus it is our sincere hope that as many of our customers as possible will avail themselves of our offer to select the proper stud dog to best serve their bitches, and to do so at one-half our regular stud fees.

The real breeder is not the fellow who can sign a check big enough to buy the best dog of any breed; but the real breeder is he who derives his real and intense interest in studying the breed, and in developing it. Many people make a good living by breeding high priced dogs, and this may be done by your own careful developing process, if you but secure the right stock to begin with. You need not invest too heavily in certain specimens-but gradually develop and breed your own. 'That's where the fun comes in-and the real profits as well. There is no hobby that will better pay a business man-and give him at the same time large rewards for his efforts. If you are fond of your dog, or dogs, they will take you into the open air, long walks, plenty of good exercise-and you'll develop both physically and in pocket-book.

If you have the right spirit and grit, you will work on and on, never getting discouraged, keeping at it-until at last, bettering your strain all the time, you will develop a winner. And your efforts will not have been in vain. Under any circumstances, winner or no winner, your time will have been well spent-and you will have profited much. Airedales are profitable, if well bred and GOOD ones, even though they never make Champions. The road to a Championship, is, as you may know, a long and hard one.

Working towards success, first get the picture of the ideal Airedale firmly in mind. IN Become acquainted. Next select your brood bitch. The best will be far the cheapest in the end. She need not herself be a winnerbut should have in her veins the blood of winners. MORE WINNERS HAVE BEEN BRED FROM SISTERS OF CHAMPION BITCHES, THAN FROM THE CHAMPIONS THEMSELVES. We do not pretend to be able to give the reason-but the fact remains. Naturally, your brood bitch should be sound and healthy. Better breed from a poor looking bitch with a good pedigree, than from a better looking individual but one without the same blue blood in her ancestry.

Your brood bitch should have no decidedly bad points. She should be well balanced. Pay particular attention to Head, Ears, Legs, Feet, Bone, Body and Coat. The Coat is not so particular as the other points in the brood bitch, for this may be corrected very largely in her off-spring by proper mating. Try, however, to secure a short, wiry coat, smoother on the sides and legs, and while hard down the back, having but little broken hair on the foreface. Avoid as a pest breeding to or from types having a long hound ear, undershot mouth or a light eyc. Don't let tendencies along these lines come into 
your strain. Watch out for a stud log that continues to produce winners. Watch the characteristics of his pups. If the types of his get seem to be such as would make a good combination with your bitch, this may be the dog for you to breed to.

A little inbreeding is required to preserve certain desired types, traits or characteristics. Never inbreed closely. That, of course, is very bad-always. Never breed a brother to a sister. Linebreeding is the thing, and is a better term than inbreeding for properly developing a worthy strain of Airedales. Line-breeding is, for example, where a dog's sire's sire and his dam's sire's sire are one and the same. This sort of thing is not only permissible-it is a good thing to develop different points of value in a certain strain.

Before you mate your bitch be sure she is in good working condition, and better a little towards lean than too fat. A healthy bitch will usually come in season about every six months. When you see indications that she is coming in, be sure to keep her by herself so there will be no danger of outside or the wrong dogs getting to her. From first to last the period usually lasts about three weeks. Bitches vary greatly as to their willingness to allow a dog to approach her. Usually the best time to mate her is when she shows by her actions that she desires the dog's presence; or, in the cases where she is shy and not inclined to show such desire at all, the time to mate will be the first day after the colored discharge (which you will notice), has dies away. If you are going to send her some distance by rail, be sure to do so in plenty of time. There are many reasons to recommend this. Usually ship her when she has been discharging about four or five days.

If your bitch ever escapes and becomes associated with a mongrel, do not destroy her as valueless for future breeding. Such is not the case. The next time she comes in season breed her to the right Stud you select-and the previous accident will have no bearing at all on the newly coming and properly bred litter.

Before mating a bitch it is always well to give her a good worming to clean her out thoroughly. She will herself be stronger and healthier and the pups themselves will be less likely to suffer from worms. The best authorities differ among themselves as to whether it is advisable to mate a bitch her first time in season. As even the most noted breeders vary in opinions on this, we feel that we may say it is optional with you on this point. Breeders also vary in opinion of whether a bitch should be served twice, or only once for best results. Being served twice will usually mean a large litter. Some claim greater strength will be given the individual pups if there is but one mating. In most cases we favor two matings-but not always. If served twice, a day's interval should be allowed in between.

After mating, and the entire in-season period being over, a bitch should be given entire freedom for the exercise that she so much needs. In the country this is easy. In the city be sure you see that she is given plenty of exercise. Be very careful she gets into no fights. 
foed her generously while she is in whelp, giving her plenty of new milk, oatmeal, brown bread and fresh, lean, law meat from twice to four times a week. She should whelp about sixty-three days after mating, often whelping a couple of days early. During the latter part of pregnancy it may be well to give her a tablespoon of vegetable oil or castor oil about every other day to help her along. A fortnight or so before she is due to whelp she should be kept where she is going to whelp so that she will become accustomed to the quarters and be quite at home and settled down when the pups are due. During this time do not house her with other dogs, but keep her as much as possible away from even the sound of them. Warmth is especially essential for the puppies until they are at least three weeks old. If this be not secured by artificial heat, you can undoubtedly find a suitable place where there is sufficient natural heat, such as a stable or cow shed where there is heat from the animals, etc. At least give her a dry, sunny kennel, with plenty of good, clean straw to whelp in; also have straw so placed that there will be a good dry place for her after whelping. She should be left to herself as much as possible, and always have plenty of fresh water handy to drink.

It is the best not to interfere with the bitch when she is in labor, as more harm than good is likely to be the result. Airedales, if healthy, will best be taken care of at this time by nature. You might excite her, and do much harm, if you try to help. When she has quite completed whelping-taking from four to twelve hours-be sure that she and the pups have good clean straw, and that the old wet straw is removed entirely, and the place disinfected. She need not be fed for some hours, but should be allowed to rest in quiet. Change the straw every day, but interfere as little as possible with the pups while they are less than a month old.

After whelping, a bitch will likely not want much to eat for a day or so; but it will be well to offer her a little boiled milk or thin gruel, in case she does desire it. A little broth poured over stale bread or boiled rice may be good. She should always have clean, fresh and cold water available. After the third day she may have more solid foods such as some meat, vegetables, scrips from the table, etc. The feeding pans should be fresh, clean and sweet.

Her health while nursing is of great importance. If her milk should be scarce or of poor quality, it will be well to secure a foster mother for the pups - not necessarily of the same breed, but at least of about the same size as their real mother. If the pups gradually make a mother's breasts sore from pulling, scratching, etc., rub them gently with marshmallow ointment, which will be good for her and at the same time will not bother the puppies. When the pups are about a week old, their tails should be docked and their dew-claws removed. A sharp pair of scissors will do the work. Take off about $\frac{1}{3}$ of the tail. Let the pups lap milk as early as possible, which will be good for them and a great relief to the mother. This should be new milk, boiled and cooled down. Also you may soon give brown bread scalded with new milk, boiled rice, or oatmeal. It is well to give the bitch castor oil about once a week while she is nursing her pups. To get strong pups it may be best not to let the bitch try to raise too many; 
if she has more than six or seven, better get a foster mother for the others. If this cammot be done, it may be best to destroy all but the best six or seven of the litter.

\section{SELLING AIREDALES AT A PROFIT}

Airedales are the most popular dogs of the present century and the natural result of this is the fact that good ones will bring very interesting prices. In fact, champions usually sell for several thousands of dollars. Airerlale pups of any sort of good breeding at all should bring not less than $\$ 15.00$ each, and the bluest blood should bring anywhere from $\$ 25.00$ to $\$ 50.00$ for pups a couple of months old. All the older dogs will bring a much larger figure. Many of the better class of magazines, which go to the people who do want and can afford to pay for the right breeding, publish dog departments in their advertising columns, in which space can be secured for a very reasonable figure and a very few such ads should be the means of disposing of several litters of pups if you are careful in handling intelligently, promptly, and in a thorough business-like manner, the inquiries that this advertisement will bring you. There are several dog magazines published which should also be used, and which probably alone would sell an entire litter to good advantage from just one advertisement.

Usually the best time to dispose of your pups is when they are from a month to several months old, even though you do so at very much less than you could get if you should raise them to be full grown dogs. We might suggest that it may often be well to sell most of the pups at around $\$ 25.00$ each while they are young, but keep one which you select as the pick of the litter and raise that one with a view to developing, showing and later selling at a really attractive price of anywhere from $\$ 200.00$ to $\$ 900.00$ or $\$ 1000.00$ or more. Or you might raise a good log from time to time, and develop him and get some good winnings behind you, and find that he is even more valuable to you to offer at public Stud, than if you sell him. A Stud dog should be carefully kept in good condition right along, and should be shown as often as possible so that he may be kept before the public eye and allow his reputation and acquaintance to grow. With a good Stud dog you can average fees of anywhere from $\$ 15.00$ to $\$ 25.00$ and a good Stud dog should yield you from a great many hundreds of dollars to over a thousand dollars a year, if your advertising appears regularly in the better dog publications. He hardly ought to average being studded more than twice a week, but at, say from $\$ 15.00$ to $\$ 25.00$ or more you can easily see for yourself that this will amount to a very worth-while sum in a year's time.

A good strong and healthy female should have, at least one and usually two litters of pups a year, and will average six to ten pups in a litter. Selling these pups at not less than $\$ 25.00$ each, you can easily estimate the amount of money that you can make in a year's time from breeding.

The Oorang Iiennels invite all friends and patrons to freely communicate with them at any and all times in legard to any sort of dog information that may be desired. 


\section{OORANG DOG REMEDIES}

After years of experimenting, we have finally selected $R E A L$ remedies for nearly every ailment peculiar to dogs. These have been tested by many famous Canine Speeialists and have proven by aetual experience to be the best, surest cures and most effective remedies ever eoneocted. These are the remedies we use here, ourselves, at the Oorang Kennels. Satisfaction guaranteed. Below is the complete list:

PRICE INCLUDES POSTAGE, EXCEPT IVHERE NOTED

Alterative Cooling Tablets, for heated blood, etc . . . . . . . . . . . . $\$ .50$

Anti-Rickets Tablets, a bone and muscle builder . . . . . . . . . . . . . . 50

Aperient Biscuits, any dog will readily take these . . . . . . . . . . . . . .

Anti-Asthmatic Tablets, for Asthma, etc . . . . . . . . . . . . . . . 50

Anti-Vomit Tablets............................... .50

Bone Builder, for Rickets, Osteroporosis, etc................ .50

Canine Elixir, for diseases of the Genito-urinary organs, etc . . ....... . .50

Consumption Capsules, of great value in the arrest and treatment of this disease

Chorea Tablets, for Chorea, St. Vitus' Dance, etc............... .5. 50

Chronic Skin Disease Tablets, for obstinate casez of Mange and Eczema... $\quad .50$

Cough Tablets, generally effect a quick cure ................... .50

Chemical Food, to give size and weight, postage $10 \mathrm{cts}$. extra..........50

Constipation Tablets, a gentle and effective laxative .............. .50

Digestive Tablets, for severe cases of indigestion. . . . . . . . . . . . 50

Diarrhoea Tablets, to relieve Diarrhoea which usually follows change of

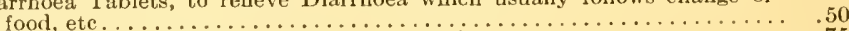

Distemper Tablets, may be used as i preventive................ .75

Dip, Pint tins, postage 15 ets. extra . . . . . . . . . . . . . . . . . . . 50

Ea: Canker Ointment, for both internal and external forms of this disease ... $\quad .50$

Eye Lotion Tablets, a safe and efficient remedy .................. 50

Eczema and Sarcoptic Mange Remedy (Oily) ................. .50

Hair Stimulant and Restorer. ............................ .50

Jaundice Tablets, valuable in treating "Yellows," etc . . . . . . . . . . . . . . .

Kidney Tablets, for Cystiti $=$ or Inflammation of the Bladder, et c......... .50

Liniment, for Rheumatism, Sprains, Bruises, Lameness, etc., and can be used for human treatment as well. . . . . . . . . . . . . . . . . . . .

Liver Tablets, a safe and reliable remedy ......................

Locurium Ointment, for wounds and cuts, bruises, etc., good for man as well

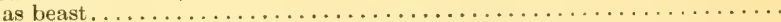

Mouth and Throat Wash, for ulceration of the mouth, sore gums, ete.... $\quad .50$

Pneumonia Tablets, administer as soon as possible .............. .50

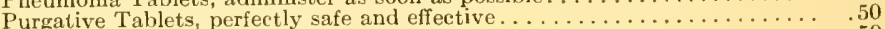

Rheumatism Tablets, for internal treatment.................. .50

Tonic and Condition Tablets, to build up after sickness and to put in bench

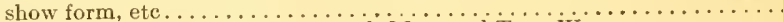

Worm Capsules, an expellent of round, Maw and Tape Worms ...........

Worm Capsules for Puppies, may be given with perfect safety to puppies from six weeks old to six months. . . . . . . . . . . . . . . . . . .

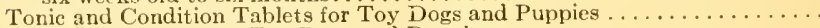

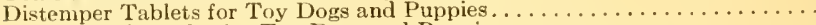

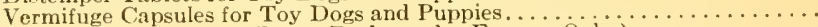
(Large Packages by Express Only.)

Spratt's Mange Remedy

$1 / 2$ Gal. Cans

$\$ 1.50$

2.00
1 Gal. Cans $\$ 3.00$ 4.00

Spratt's Eczema and Sarcoptic Miange Remedy (Óintment) $1 \mathrm{lb} \ldots \ldots \ldots \ldots 2.00$

Worm Capsules, Kennel size.......................... 5.00

Worm Capsules, For Puppies, Kennel Size..................... 5.00

(These packages contain 15 times the quantity packed in a 50 cent package.)

These prices include postage, except where noted. Many a prize winner has been cured of ailments by one or the other of these remedies. We have hundreds of testimonials in our files testifying to their absolute euring qualities. Look over the list, pick out what you want, and mail your order to

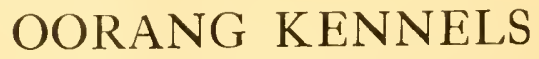

LARUE, OHIO 


\title{
CONDITIONING AND BOARDING KENNELS
}

The Oorang Conditioning and Boarding licmnels is one of the best equipped and most sanitiry establishments of its kind in the country. These kennels are located four miles distant from the main kennels at LaRue, and occupy twenty-five acres of ground securely fenced in and well shaded. These kennels are available to anyone, anywhere, who may wish to send a dog here to be boarded, conditioned or treated. Dr. Rush, the Canine Specialist, in charge, is admirably suited for this work as his broad experience has acquainted him with every possible dog ailment, also the quickest and most effective methods of treating them. In connection with these kennels there are special whelping quarters which are open to outside bitches. This service insures for those taking advantage of it, a proper care during this important time and the assurance of good pups.

\section{INSTRUCTIONS}

We positively will not accept any dogs suffering from Rabies or Distemper.

Dogs must have good collars.

Dogs must be brought, or fully prepaid if sent by express.

Notify us prior to shipping and give the kennel name of the dogs.

All dogs received and held at owner's risk. We assume no responsibility for accidents or losses, but all dogs will be given the best of care.

\section{RATES}

Boarding, Conditioning and treating all breeds of dogs........................ $\$ 2.50$ per week.

Special Whelping quarters for brood matrons, including puppies 11 p to two weeks of age...... 2.50 per week.

Additional charges for puppies after two wceks and up to six weeks of age, each......... .25 per week.

Additional charges for puppies after six weeks and up to twelve weeks, each.............. .50 per week. Puppies over twelve weeks of age......... 2.50 per week.

Reasonable extra charges will be made for all surgical operations.

\section{OORANG KENNELS}

\author{
LARUE, OHIO
}




\section{MOORE'S TOXIN}

\section{A SURE CURE FOR DOG DISTEMPER}

Moore's 'Toxin is a solution of sterilized germs of dog distemper. It was discovered by Dr. Moore, after devoting the greater part of his life in analyzing the cause, and experimenting on a cure.

The Toxin is injected into the $\operatorname{dog}$ and passes into its system. Immediately the destruction of distemper germs begins, and continues until they are wholly eliminated. The condition of the dog after this has taken place depends entirely upon the ravages made by the disease before it was annihilated. If he had not become very ill, he will not become so. If he was weak, he will still remain weak. If he has not sufficient strength to rally, he will die. Moore's Toxin does not inject new life into dead or dying dogs-it simply drives out distemper.

\section{AN IMMUNIZING AGENT}

We have adjunct remedies, which are powerful food tonics to aid the dog on the road to recovery. If you do not want to take chances on nursing dogs back to health after distemper, immunize and save them from it. Moore's Toxin injected into a dog or pup which has not become infected with distemper, will render him immune from the disease for at least one year, and in most eases longer.

\section{PRICES}

Our price is $\$ 2.00$ per vial-each vial containing one dose, sufficient to cure or immunize one dog. Adjunct remedies sell for $\$ 1.00$ per bottle. We have two of these remedies, and in any ordinary case, one bottle of each will bring the dog back into shape. The hypodermic syringe, to be used for injecting the Toxin, sells for 50 cts. No special syringe is necessary, as any ordinary hypodermic syringe sold by your druggist will answer the purpose. Address all your orders to

\section{OORANG KENNELS}

LARUE, OHIO 


\section{PATENT DOG SOAP}

(White)

FOR FLEAS, ETC.

Has it ever oceured to you that your dog is not immune from poison while his coat is infected with fleas? It has been proven by famous canine specialists that many cases of bloocl poison have been the direct result of fleas. This being the case, it behooves every dog owner to bathe his dog with a soap that will rid him of these pests. The Patent Dog Soap kills fleas, besides keeping the dog's skin free from scurf and preventing Mange. It has been successfully used by many dog owners in preparing their pets for exhibition as it leaves the coat smooth and glossy.

This Soap contains no Carbolic Acid or Coal Tar, but is nicely perfumed and produces a fine lather. It is recommended by some of the most famous kennel owners in the country, and it is the soap we use here at LaRue.

Price per cake-25 ets postpaid.

\section{PATENT ANTISEPTIC SOAP}

(Black)

\section{VETERINARY USE, ETC.}

This must not be confounded with Patent White Dog Soap. This soap contains certain ingredients of powerful germicide and is the result of a long series of careful experiments and tests. It is intended for use as a germicide, disinfectant, for the treatment of wounds, etc., and may be used with perfect impunity except internally.

One cake of this soap dissolved in forty pints of water may be used as a disinfectant of kennels, benching, etc., and will kill most germs in a few minutes. The spread of distemper may thus be checked. It is also used very extensively in a sterilizer for veterinary instruments.

Price per cake-50 cts. post paicl.

\section{OORANG KENNELS}

LARUE, OHIO 


\section{KENNEL REVIEW}

\section{A REAL, DOG MAGAZINE}

When you buy an Oorang Airedale, there are two things you should have - A good magazine devoterl to dogs - A good book portraying and exploiting the Airedale. The KENNEL REVIEIV is absolutely the best, up to the minute monthly magazine in the country. It consists of thirty-two pages brim full of interesting Airedale news, hunting stories and photographs from life of the most famous Airedales in America and England.

Every owner of an Airedale will find this magazine worth many times the small cost and after becoming a regular reader will be surpriser at the increased interest and genuine pride he takes in his Airedale. Other Airedale lovers in all parts of the world are regular readers of The Kennel Review, and in its columns tell about the many intelligent traits of their dogs at home and in the liunting fields, about their blue ribbon winners at the big Dog Shows held throughout America, their varied experiences in rearing, caring for and training puppies.

\section{AIREDALES FOR PROFIT}

Thousands of Airedale lovers in all parts of the world are making a big profit raising Airedales, the total sales from one well known kennel during the past year came close to the hundred thousand dollar mark, which, my dear reader, you may find hard to believe, but nevertheless it is a fact. Many well known kennels sell from five to ten thousand dollars worth of stock annually.

You, who own your first Airedale and who have never considered the possibilities of the interesting oecupation of $\mathrm{dog}$ breeding will glean worlds of valuable information along this line by becoming a regular reader of The Kennel Review and so we are sure you will thank us for telling you something about this most interesting doggy magazine.

For the benefit of our many patrons we have arranged with the Publishers of this magazine to receive and forward subscriptions and if you will forward us the subscription price of one dollar, we will have the magazine come to your address every month for one year. Do not put it off-send today and learn how to get the most real enjoyment out of that fine pup of yours.

Price $\$ 1.00$

Send All Orders to

\section{OORANG KENNELS}

LARUE, OHIO 


\title{
ALL ABOUT AIREDALES
}

\author{
SIXTH EDITION
}

$\mathrm{Bl}$

R. M. PALMER, A. B.

The all-round superiority and ever-increasing popularity of the Airedale is making this book the most popular and widely read dog book of the present day. "All About Airedales" is a book of general information, valuable to dog lovers and owners, breeders and fanciers. It is profusely illustrated with selected photographs of noted dogs and rare scenes. It reviews the Airedale Terrier from its origin up to the present time, discussing its characteristies, physique, etc. Below, we are listing the various chapter headings of the booklet, thereby giving an idea as to its contents. Read these, and you will appreciate somewhat the comprehensiveness of this volume.

Chapter I, Page 9 -Origin and General Characteristics of the Airedale Terrier.

Chapter II, Page 23 - Physique and Standard Type of the Aircdale Terrier.

Chapter III, Page 29 -The Kennel; How to Arrange It.

Chapter IV, Page 33 -Feeding.

Chapter V, Page 39 -Breeding.

Chapter VI, Page 51 -Puppies; Their Care; How to Feed and Raise Them sucessfully.

Chapter VII, Page 63 - Healthy Airedales.

Chapter VIII, Page 75-Diseases and Their Treatment.

Chapter IX, Page 89 - Showing Airedales.

Chapter X, Page 97 -Airedales vs. Hounds.

Chapter XI, Page 105 - Training and Development for Sport.

Chapter XII, Page 111-Airedales in Canada, Airedale Anecdotes, Selling Airedales, Advertisements.

Our Price for this book with cloth binding is $\$ 1.50$-paper cover, $\$ 1.00$ (postpairl.)

Let us have your order at once, as it will be a most valuable addition to your library.

Send Your Order to

\section{OORANG KENNELS}

LARUE, OHIO 


\section{DOG ACCESSORIES}

We have a complete assortment of accessories and necessities that are absolutely essential to every dog owner.

By purchasing these accessories from us, you are assured of the highest quality obtainable at very reasonable prices.

Here is a partial list of items we have in stock at all times-but write us for anything you may want.

\section{Collars}

Chains

Leads

Stripping Combs

Dog Feeds of all kinds

Dog Crates, etc.

The limited amount of space in this booklet does not permit the description and prices of all the accessories we handle.

Write us about anything you want in the way of Sporting Goods and Equipments. Any particular information you desire will be sent upon application.

\section{OORANG KENNELS}

LARUE, OHIO 
Completely designed and excculed in the studios of the Sloman Aduertising Co,Dayton. 0 . 

LIBRARY OF CONGRESS

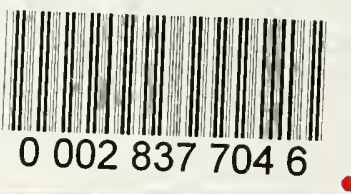

